\title{
LA IDEA DE ESPAÑA EN EL DISCURSO «SERVIL» (1808-1814)
}

\section{The idea of Spain in Spanish reactionary discourse (1808-1814)}

\author{
JUAN PABLO DOMÍNGUEZ \\ Universidad de Navarra \\ jdfernandez@unav.es
}

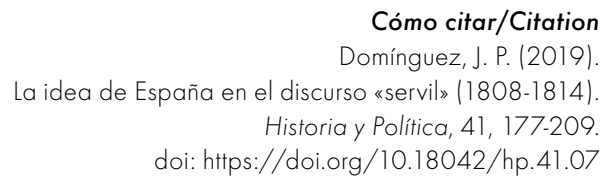

(Recepción: 09/09/2017; Evaluación: 11/11/2017; Aceptación: 10/02/2018; Publicación: 13/05/2019)

\section{Resumen}

El afán de dar prioridad temporal al nacionalismo liberal sobre el nacionalismo reaccionario —y, más en concreto, de afirmar que el «nacionalcatolicismo» no surgió hasta la segunda mitad del XIX — ha llevado a la historiografía reciente a asumir las siguientes ideas sobre el discurso «servil»: 1) que se oponía a los Bonaparte por motivos religiosos y no patrióticos; 2) que era férreamente absolutista y no otorgaba ningún papel a la nación en sus esquemas políticos; 3) que rechazaba la palabra "patria» y aún más la palabra «nación»; 4) que, lejos de apelar al pueblo y de identificarse con él, lo temía profundamente; 5) que no invocó a los héroes de la patria ni elaboró un relato histórico nacional opuesto al de los liberales; 6) que no esgrimió la idea de la "antiespaña»; y 7) y que, si bien dio muestras de xenofobia, no exaltó la propia identidad nacional. Sin entrar en la compleja cuestión del origen y los rasgos esenciales del nacionalismo contemporáneo, este artículo pretende demostrar que los textos escritos entre 1808 y 1814 por los reaccionarios españoles contradicen claramente estas asunciones historiográficas. 


\title{
Palabras clave
}

Serviles; reaccionarios; nacionalismo español; nacional catolicismo; Guerra de la Independencia.

\begin{abstract}
Many recent scholars have assumed that liberal nationalism arose long before reactionary nationalism, and more specifically, that Spanish "national Catholicism" did not emerge until the second half of the $19^{\text {th }}$ century. This assumption has led a number of noted historians to embrace the following ideas concerning the political discourse of the so-called "serviles": 1) that it opposed the Bonapartes for religious and not patriotic reasons; 2) that it was thoroughly absolutist and did not grant any role to the nation in its political schemes; 3 ) that it rejected the word patria and even more the word nation; 4) that it deeply feared the people; 5) that it did not invoke the heroes of the fatherland or elaborate a national historical narrative opposed to that of the liberals; 6) that it did not espouse the idea of the "anti-Spain"; and 7) and that it showed signs of xenophobia but did not exalt the Spanish national identity. Without pretending to solve the much debated question of the origins and nature of modern nationalism, this article shows that the reactionary texts published in Spain between 1808 and 1814 do not support any of these historiographical assertions.
\end{abstract}

\section{Keywords}

Counterrevolution; anti-liberalism; Spanish nationalism; National Catholicism; Peninsular War. 
I. INTRODUCCIÓN. II. INDEPENDENCIA. III. ABSOLUTISMO. IV. NACIÓN. V. PATRIA. VI. PUEBLO. VII. GLORIAS DE ESPAÑA. VIII. LA ANTIESPAÑA. IX. IDENTIDAD NACIONAL. X. CONCLUSIONES. BIBLIOGRAFIA.

\section{INTRODUCCIÓN}

En las páginas de Mater dolorosa, José Álvarez Junco sostiene que las naciones y los nacionalismos surgieron cuando las revoluciones liberales asignaron derechos políticos a los pueblos. De ahí que, en su opinión, no fuese hasta las Cortes de Cádiz que «España, siguiendo a Francia, se inventó la nación».

Según esto, la insurrección antinapoleónica de 1808 no pudo ser una guerra de la independencia, ya que en la España de entonces no había nacionalismo alguno que reclamase una nación independiente. El patriotismo de 1808 no fue, para Álvarez Junco, más que celo religioso y xenofobia antifrancesa $^{2}$. En su opinión, aunque los insurrectos de 1808 emplearan «la consigna política de Dios, patria y rey», vitorearon, «sobre todo, al catolicismo y sus dogmas» y olvidaron o dejaron "muy en último lugar» a la nación ${ }^{3}$.

Asimismo, según Mater Dolorosa, los enemigos del liberalismo gaditano rechazaron de plano la «idea de nación", y por eso en sus escritos dieron más importancia a Dios y al rey que a la patria y mostraron «repulsión» ante el término nación ${ }^{4}$.

Álvarez Junco admite que antes de 1808 existía un "patriotismo étnico» basado en la identificación entre Espańa y el catolicismo. Y hasta ve en los antiilustrados del siglo xviII «los orígenes del futuro nacional-catolicismo». Pero insiste en que la evolución hacia el «nacional-catolicismo» se truncó con la Revolución francesa. Hasta entonces, en su opinión, el clero ultramontano había sido más bien "antiabsolutista», pero el estallido revolucionario lo empujó a exaltar los derechos de la monarquía absoluta y a rechazar, por tanto, los de la nación 5 .

Álvarez Junco (2001): 60, 129-130 y 310.

Álvarez Junco (1994): 80 y 89-91.

Álvarez Junco (2001): 305.

Ibid.: 306 y 349 .

Ibid.: 336 y 340 . 
Según Mater dolorosa, el discurso «nacional-católico» no empezó a construirse hasta los ańos 40 del siglo XIX, cuando escritores como Balmes, Zorrilla o Fernán Caballero introdujeron «en los ambientes conservadores la idea de "nación"» al asumir la "creencia romántica» en el protagonismo histórico de las naciones y difundir la idea de España como nación esencialmente católica y monárquica. Pero no fue hasta los sesenta cuando los conservadores españoles - queriendo identificar «la entidad nacional llamada "España" con el catolicismo" para responder a la ya asentada historiografía liberal- crearon un nuevo relato histórico que atribuía a Santiago, Recaredo y Pelayo la paternidad de la patria, presentaba a judíos y moriscos como extraños a la nación, asignaba a la Inquisición una misión histórica ineludible, ensalzaba la España de los Reyes Católicos y los Austrias, y atribuía la decadencia nacional al reformismo antiespañol del siglo xviII. Finalmente, y siempre según Álvarez Junco, «la construcción intelectual del nacional-catolicismo» culminó con Menéndez Pelayo y su idea de la "anti-España» ${ }^{6}$.

Algunas de estas tesis son anteriores a la aparición de Mater Dolorosa en 20017. Pero fue la gran difusión de esta obra lo que puso en jaque a otras interpretaciones que atribuían la revuelta antinapoleónica de 1808 a un «nacionalismo extremo» y presentaban a los enemigos del liberalismo gaditano como defensores del volksgeist que, al crear la idea de una "antiespaña» liberal e ilustrada, iniciaron la lucha entre las «dos Españas» ${ }^{8}$.

En las últimas décadas, hasta quienes subrayan la relevancia política que la idea de nación alcanzó en la España del XviII suelen asumir que los patriotas ilustrados ignoraban «el sentido de lealtad excluyente y de reconocimiento de una voluntad colectiva que - jacobinismo y romanticismo de por medioconfigurarán el nacionalismo contemporáneo»?. Y aunque algunos historiadores apuntan a la existencia de una idea conservadora de nación en la España dieciochesca, otros insisten en que, a raíz de la Revolución francesa, las voces «patria» $\mathrm{y}$ «nación» se volvieron incómodas para los conservadores españoles ${ }^{10}$.

El éxito de Mater Dolorosa no ha impedido, sin embargo, que algunos autores sigan hallando evidencias de patriotismo independentista en los

\footnotetext{
Ibid.: 390, 407, 417 y 457.

Maravall (1967): 26; Seoane (1968): 63, y Vilar (1971): 521.

Herrero (1971): 250-251; Moreno Alonso (1989): 72, y Botti (1992): 31

Fernández Albaladejo (2007): 146.

10 Fernández Sebastián (1994): 48-53; López-Cordón Cortezo (2006): 155; Sánchez-Blanco (2007): 41-54; Hocquellet (2008): 121-124; Medina (2009): 54; Portillo Valdés (2009): 992; Fuentes (2013): 175; Millán (2014): 61-62, y Pedro Rújula (2016): 73-95.
} 
discursos de $1808^{11}$. Francisco Sánchez-Blanco llega a afirmar que los «patriotas» conservadores alentaron la «resistencia popular» con argumentos «nacional-católicos» que ya habían empleado en la guerra de 1793-1795 contra la Revolución francesa ${ }^{12}$. Richard Hocquellet, por su parte, sostiene que el patriotismo de 1808 se dividió muy pronto en dos vertientes: una que concebía la nación como producto histórico compuesto de distintos territorios y estamentos, y otra que empezaba a diseñar la «nación moderna», entendida como proyecto político y asociación de individuos ${ }^{13}$.

En cuanto a los adversarios del liberalismo gaditano, varios autores piensan que sí tuvieron una idea de nación, por muy distinta que fuese a la nación soberana, unitaria y ciudadana de los liberales ${ }^{14}$. Algunos sostienen que, en tiempos de la Guerra de la Independencia, los conservadores espańoles adaptaron a sus intereses el lenguaje nacionalista surgido en la Revolución francesa $^{15}$. Así, Juan Francisco Fuentes opina que —en el clima de «exaltación patriótica» de la Guerra de la Independencia - los absolutistas asumieron «parte del lenguaje y de la mitología de la soberanía nacional». Considera, no obstante, que se sentían muy incómodos ante las palabras "patria» y — sobre todo- «nación», y que por eso abandonaron su patriotismo circunstancial e impostado en cuanto Fernando VII regresó a España ${ }^{16}$. Borja Vilallonga afirma que el nacionalismo católico nació al mismo tiempo que el liberal, pero pasa muy por encima del discurso «servil» y señala a Balmes como el primer teórico de ese catolicismo nacional ${ }^{17}$. Jesús Millán admite la temprana existencia de ideas de nación alternativas a la liberal. Sin embargo, cree que, en tiempos de las Cortes de Cádiz, fueron «desplazadas por el triunfo del concepto contractualista de la soberanía nacional ${ }^{18}$.

Jesús Torrecilla ha sido, tal vez, quien más se ha alejado de las tesis de Álvarez Junco. Sus trabajos recientes han invertido por completo la trama de Mater dolorosa al afirmar que ya hubo un fuerte nacionalismo antiilustrado en la Espańa del siglo XVIII y que los liberales del xIX construyeron su

\footnotetext{
11 Moliner (2007): 254-55; Alonso (2008): 75-103, y Castro (2011): 37-66.

12 Sánchez-Blanco (2007): 46 y 53.

13 Hocquellet (2008): 134-157.

14 Varela Suanzes-Carpegna (2007): 197-205; Pérez Garzón (2007): 17 y 402-410; García Cárcel (2007): 226-227 y 247; Elorza (2011): 63-72; Rubio Pobes (2014): 119122, y García y Escrig (2016): 67.

15 Eastman (2012): 33-44.

16 Fuentes (2014): 179-180.

17 Vilallonga (2014): 307-331.

18 Millán (2014): 60-62 y 72.
} 
discurso patriótico en respuesta a este previo y exitoso nacionalismo conservador ${ }^{19}$.

Por el contrario, los historiadores del llamado nacionalcatolicismo suelen seguir a pies juntillas el relato de Mater dolorosa ${ }^{20}$. Manuel Suárez Cortina, por ejemplo, repite que el discurso «servil» fue «declaradamente antinacional», que Balmes hizo «el primer esfuerzo por conciliar catolicismo y nación» y que el «mito nacionalizador del nacionalcatolicismo» - construido en torno a Santiago, los Reyes Católicos y Trento- no se afianzó hasta la Restauración canovista $^{21}$. Por lo general —obviando los matices que el propio Álvarez Junco añade a su tesis sobre la tardía "fusión de la identidad española con el catolicismo»-, los historiadores del «nacionalcatolicismo» se limitan a repetir que «hasta mediados del siglo xIx, el catolicismo se enfrentó a la idea de nación» y que solo entonces se emprendió «una reelaboración de la historia española basada en la identificación esencial de la nación española y el catolicismo» ${ }^{22}$.

\section{INDEPENDENCIA}

Antes de 1808, el "derecho de independencia», que exigía la no intromisión de "nación alguna en el gobierno ajeno», ya había sido expresamente enunciado; y la posibilidad de una invasión, claramente contemplada ${ }^{23}$. Un sermón de 1805 afirmaba: «Si la patria es invadida, la religión nos quiere a todos soldados $\aleph^{24}$.

Ya en el siglo XVII, los historiadores afirmaban que "la soberanía de España» había comenzado, o bien al desligarse del Imperio romano «en tiempo de los reyes godos", o bien cuando, tras resistir a la invasión musulmana, «quedaron los españoles libres» y pasó «a ser señora la nación que hasta entonces había vivido rendida $»^{25}$.

A finales del XviII, las posturas no habían cambiado en exceso. Para Juan Pablo Forner, la historia de la «nación considerada como una sociedad civil

19 Torrecilla (2009a): 99; Torrecilla (2009b), y Torrecilla (2016).

20 Álvarez Chillida (2002): 96; Muñoz Mendoza (2012): 61-62; Saz (2012): 263-268, y Louzao Villar (2013): 75-78.

21 Suárez Cortina (2008): 223-262.

22 Álvarez Junco (2001): 194, 306, 308, 333 y 349; Esteban de Vega (2005): 92, y Rina Simón (2015): 87.

23 Olmeda y León (1771): I, 249-250, y Torrecilla (2009a): 75-77.

24 Miera Pacheco (1809): 3.

25 De la Puente (1612): 156, y Salazar y Mendoza (1770): 61-63. 
independiente de imperio o dominación extranjera» empezaba con los godos ${ }^{26}$. Por el contrario, José Ortiz y Sanz consideraba que solo con la Reconquista quedó «libre España de señores extraños» ${ }^{27}$. Otro autor de la época — para quien España no era "el suelo» sino «el pueblo»— afirmó: «Diez siglos precisamente han de ser desde que España es España; esto es, pueblo independiente y sui juris $\aleph^{28}$.

En la España del xvıII, hasta los más monárquicos admitían que, en sus orígenes, la nación había pactado con el rey las leyes fundamentales que establecían la sucesión y los límites del poder real ${ }^{29}$. Según esto, en una nación soberana -es decir, regida por sus propias leyes fundamentales y no "por derecho de conquista" - quedaba descartado un absolutismo tal que permitiese al monarca disponer del reino a su antojo ${ }^{30}$. De ahí que, en 1808, el obispo Pedro Quevedo - que pronto mostraría su rechazo a la idea liberal de soberanía nacional - pudiera decirle a Napoleón que era «la nación misma, con la independencia y soberanía que la compete» la que debía reconocer a su legítimo rey ${ }^{31}$.

Desde 1808, los «patriotas» espańoles — por más conservadores que fueran- presentaron el conflicto armado como una «guerra nacional» sostenida por el pueblo «en masa», muy distinta a las habituales contiendas «entre los príncipes $»^{32}$. La idea de que los españoles debían «recobrar su libertad e independencia», incluyendo el "dominio de su territorio», aparece continuamente en sus escritos. ${ }^{33}$ En ellos se repite que los españoles luchaban por «la libertad e independencia de la nación", amenazada por un déspota extranjero que — tras apresar a quien reinaba «según la voluntad de la misma nación»— aspiraba a "conquistar la Espańa» para convertirla en "una provincia de Francia», destruir sus «leyes fundamentales» y despojarla del «natural irrevocable derecho y absoluta libertad de elegirse cabeza, rey o gobierno ${ }^{34}$.

Los predicadores fernandinos insistieron en que la "nación española» —opuesta siempre al dominio de "nación alguna extranjera»— requería

\footnotetext{
26 Forner (2010): 9.

27 Ortiz y Sanz (1796): iii y v.

28 Cartas de un español (1788): 98-99.

29 Pérez y López (1785): 181 y 198; Villanueva (1793): 124-127 y 142; Peñalosa y Zuñiga (1793): 52, 59 y 440, y Dorca (1805): 52.

30 Millán (2011): 342, y Alvarado (1846): 56.

31 Quevedo Quintano (1808): 2.

32 Francisco José de Molle, cit. en Eastman (2005): 269.

33 Diario de Santiago, 5-VIII-1808, p. 257, y Alvarado (1811): 35.

34 Pérez Villaamil (1808): 2 y 45; Solchaga (1809): 12; Borrull (1810): 56; Lardizábal (1811): 33, y Carnicero (1813): II, 151.
} 
«nuevos héroes dignos del nombre español», dispuestos a dar «su sangre por la independencia de la patria ${ }^{35}$. La guerra antinapoleónica se asoció sobre todo a la memoria de la Reconquista, que se interpretaba como una gesta en que la "gente española» —al «libertar el suelo» español «de los inmensos ejércitos mahometanos»— había logrado «a costa de sangrientos combates su independencia ${ }^{36}$. Según esto, la España de 1808 volvía a estar en peligro de "perder la independencia, que conquistó de los agarenos en ocho siglos de batallas y de victorias ${ }^{37}$. Y los españoles debían luchar con denuedo para alcanzar por segunda vez «la gloria que ninguna otra nación ha tenido, de renacer de sus mismas cenizas» ${ }^{38}$.

En los discursos de la época, la «salvación de la patria» se vincula con frecuencia a la mera expulsión de los ejércitos franceses ${ }^{39}$. En las proclamas tras las victorias militares "patriotas» pueden leerse frases como: «Ya tenéis patria; ya sois una gran nación». O: «Españoles, ya somos nación, ya respiramos» ${ }^{40}$. En 1811, el nada liberal general Castaños afirmó: «La nación española no puede acabarse, y se han de acabar los franceses algún día, porque estos son transeúntes, y aquella tiene raíces inmortales» ${ }^{41}$.

\section{ABSOLUTISMO}

Siguiendo a Javier Herrero, Álvarez Junco ve a los «serviles» como absolutistas. El problema es que, en este punto, Herrero hizo una interpretación más que forzada de las fuentes ${ }^{42}$. El propio Álvarez Junco pone como ejemplo de absolutismo una obra del jesuita Hervás y Panduro que, en realidad, afirma expresamente «la necesidad en que se hallan los príncipes de dividir su poder con otros» y que, de hecho, fue censurada en tiempos de Carlos III por criticar el regalismo y por elogiar a autores favorables a la «soberanía del pueblo» ${ }^{43}$.

Frente a los tópicos historiográficos sobre el absolutismo «servil», María del Mar Alarcón ha señalado recientemente que muchos críticos del liberalismo

\footnotetext{
Gutiérrez y Polop (1809): 8, 9 y 27.

Diario politico de Mallorca, 30-6-1808, p. 62, y Pérez Villaamil (1808): 46.

Diario de Santiago, 5-8-1808, p. 257.

Alvarado (1812b): 23-24.

Aviso importante (1811): 11, y Colón (1811): 75.

Proclama a los vencedores (1808): 80, y Diario de Mallorca, 4-9-1812, 999.

Gaceta de la Junta-Congreso del Reino de Valencia, 7-5-1811, p. 507.

Herrero (1971): 98, y Cevallos (1776): 147-153.

43 Hervás y Panduro (1807): II, 123 y 126, y Amat (1838): 174.
} 
gaditano reprobaron también la «tiranía» y el «despotismo» de anteriores gobiernos $^{44}$. Joaquín Varela, por su parte, ha afirmado que los diputados «realistas» no siguieron la «senda absolutista» que les supone Mater dolorosa ${ }^{45}$. Y Javier López Alós ha insistido en que - frente a la «soberanía absoluta de la nación» propia del liberalismo y a la «soberanía absoluta del rey» preferida por los afrancesados- los «reaccionarios católicos» abogaron por una "soberanía compartida» ${ }^{46}$.

Estos rasgos antiabsolutistas enlazan el discurso «servil» con el de aquellos ultramontanos que, en tiempos de Carlos III y Carlos IV, denunciaron la «persecución de la Iglesia» desatada por Godoy y otros ministros empeñados en «sojuzgar» al clero para extender la "soberanía de los príncipes civiles» ${ }^{47}$. En algunos «serviles» se advierte también la herencia del partido aristocrático que, a lo largo del siglo XviII, defendió el papel de la nobleza como contrapeso al poder real ${ }^{48}$.

En tiempos de las Cortes de Cádiz, los ultramontanos insistieron en que el despotismo liberal había "dejado en zaga al de Godoy» y criticaron a los «diputados filósofos» por imitar el gran error del reformismo borbónico: conceder a la autoridad civil una «ilimitación de poderes» contraria a la autoridad eclesiástica ${ }^{49}$. El resentimiento ultramontano, silenciado hasta entonces por la censura, salió a la luz durante la Guerra de la Independencia. Como afirmó el liberal José María Calatrava, los «serviles» se atrevieron entonces a decir cosas que nunca «hubieran dicho en tiempo de Carlos III» $»^{50}$.

Se atrevieron, por ejemplo, a criticar el «despotismo ministerial» que había llevado a Espańa "hasta el borde de la ruina"s1. Y a lamentar los Decretos de Nueva Planta, las presiones contra los fueros vascos y navarros y otras muestras del «exceso del soberano poder» que había caracterizado al siglo XVIII ${ }^{52}$. Algunos llegaron a afirmar que el abatimiento nacional ante «los empujes del despotismo» había empezado ya en el siglo xvi, cuando la corona

Alarcón (2017): 351-355.

45 Varela Suanzes-Carpegna (2013): 212.

46 López Alós (2011): 205-214.

47 Memorial ajustado (1768): 178; Menéndez de Luarca (1812): 169, y Cevallos (1813): 38.

48 García de la Huerta (1970); Demerson (1971): 137-158; Egido (1971); La Parra (2007): 255-267; Calvo y González (2008): 327, y Alarcón (2012): 165-186.

49 Aviso importante (1811): 44; El Sensato, 12-XII-1811, p. 181, y Alvarado (1816): 10 y 11.

50 Discusión del proyecto (1813): 552.

51 Freire Castrillón (1809): 17; Múzquiz y Aldunate et al. (1811): 12; Representación y manifiesto (1814): 14, 16, 17, 41, 45, 46 y 58, y Artola (1976): II, 143.

52 Borrull (1810): 75-78; Pérez de Culla (1811): 7; Hermida (1812): 12 y 33, y Alvarado (1846): 57. 
cayó en manos de «extranjeros flamencos» que extinguieron «la antigua libertad castellana» al alterar «la primitiva representación observada en Espańa desde los primeros concilios de Toledo ${ }^{53}$.

Hay que tener en cuenta, además, que la soberanía nacional no fue, ni de lejos, el principal punto de desencuentro entre liberales y «serviles». El art. 3 de la Constitución — según el cual la «soberanía nacional» residía «esencialmente en la nación»- tuvo solo veinticuatro votos en contra, mientras que fueron sesenta los diputados que se opusieron a abolir la Inquisición. El caso de Vicente Terrero evidencia que era posible ser, al mismo tiempo, un radical defensor de la soberanía popular y un ardiente apologista de la España inquisitorial y antiilustrada ${ }^{54}$.

Desde su exilio británico, José María Blanco White lamentó que las Cortes se empeñaran en «hacer existir la patria» sobre el «dogma» liberal de la «soberanía nacional». En su opinión, los reaccionarios españoles habrían aceptado sin problemas la soberanía de la nación si esta no se hubiese tomado «numeralmente como una horda de bárbaros que entran por la primera vez en sociedad, sino como un cuerpo político compuesto de jerarquías, en cuya escala está el primero el rey "s5. Efectivamente, varios reaccionarios afirmaron que "la nación con su rey es verdaderamente soberana " ${ }^{56}$. Y algunos sostuvieron que, en ausencia del rey, la soberanía estaba interinamente «en toda la nación espańola $\$$. Otros, sin embargo, estimaron que, una vez transferida al rey la soberanía originaria de la nación, el «fiel y virtuoso pueblo español» no podía ni quería reclamar unos «derechos de soberanía» que ya no le correspondían $^{58}$. En todo caso, nada de eso era incompatible con atribuir a las tradicionales Cortes una auténtica «representación nacional» capaz de contrapesar el poder real ${ }^{59}$. Es cierto que muchos «serviles» dudaron que esa representación se diera en las Cortes de Cádiz, que no reunían los tres brazos del «cuerpo político de la nación ${ }^{60}$. Pero otros tan destacados como Francisco Alvarado rechazaron la división estamental por considerar que los diputados no debían

\footnotetext{
Colón (1811): 47-48; Carnicero (1813): I, 40-42, 101 y 104, y Hermida (1812): 9-10.

Pérez Girón (2012).

El Español, 30-11-1811, p. 149.

Lardizábal (1811): 30.

57 Diario de las discusiones y actas de las Cortes, 25-8-1811, p. 15, y Quevedo Quintano (1813): 20.

58 Caro y Sureda (1809): 32, y Aviso importante (1811): 41.

59 Artola (1976): II, 416.

60 Múzquiz y Aldunate et al. (1811): 9.
} 
tener «más carácter que el de católico, el de español y el de representante de la nación ${ }^{61}$.

Para buena parte de los reaccionarios, la «nación española» tenía «en sí el poder de gobernarse», pero no podía ejercerlo a espaldas de las «leyes fundamentales» que ella misma había pactado con el rey ${ }^{62}$. Si rechazaron la absoluta soberanía de las Cortes para establecer una Constitución fue precisamente porque creían que España había tenido «siempre su constitución o sus leyes fundamentales» ${ }^{63}$. Según el discurso «servil», bastaba con poner fin a los «muchos y muy perjudiciales abusos» provenientes de haber «abandonado nuestra constitución" para impedir que los españoles volvieran «a ser el juguete de un ministro y de un favorito». Supuestamente, esa «antigua constitución» — cuyo olvido había «acarreado a la nación tantas desgracias»— hacía de España una «monarquía moderada» o «limitada» en la que el rey no podía gobernar «sin contar con la nación y su consentimiento» ${ }^{64}$.

Los reaccionarios creían que el «derecho de establecer las leyes fundamentales» no pertenecía «ni a la nación sin el rey, ni al rey sin la nación» ${ }^{65}$. La Constitución era, a sus ojos, un pacto histórico que no podía romperse unilateralmente y de cuya pervivencia dependía la de la patria. Según el discurso «servil», España no requería «una nueva constitución» porque no había «dejado de ser nación» en 1808; muy al contrario, al atenerse entonces «a su rey legítimo, a su constitución, y a sus leyes y religión», los españoles habían conservado "la unidad y el ser de la nación» ${ }^{66}$. Por eso los más subversivos reaccionarios acusaron a las Cortes de Cádiz de hacer lo que ni el mismo Napoleón había logrado: abolir «de un golpe la constitución nacional» ${ }^{67}$.

Se ha dicho que los reaccionarios veían la patria «más como el lugar donde nacieron nuestros padres que como un territorio sometido a una misma legislación, a un poder o comunidad política ${ }^{68}$. Lo cierto es, sin embargo, que los «serviles» criticaron a los liberales por presentar la nación en términos abstractos, como un mero agregado de individuos, olvidando que una nación,

\footnotetext{
61 Alvarado (1846): 37.

62 Diario de las discusiones y actas de las Cortes, 29-8-1811, p. 76.

63 Diario de las discusiones y actas de las Cortes, 25-8-1811, p. 21; Diario de las discusiones $y$ actas de las Cortes, 18-1-1812, p. 320.

64 Aviso importante (1811): 11; Alvarado (1846): 30, y Carnicero (1813): IV, 14.

65 Puigserver (1815): 78.

66 Diario de las discusiones y actas de las Cortes, 18-1-1812, p. 320; Diario de las discusiones y actas de las Cortes, 29-8-1811, p. 82.

Múzquiz y Aldunate et al. (1811): 19.

68 Suárez Cortina (2008): 231.
} 
«entendida políticamente», no es una «reunión de hombres en confuso» sino «bajo de un cierto gobierno y constitución que es el vínculo que forma su unión» ${ }^{69}$.

\section{NACIÓN}

En apoyo de sus tesis, Mater dolorosa aduce un párrafo del reaccionario francés Augustin Barruel contra «le nationalisme, ou l'amour national». Álvarez Junco parece ignorar que dicho párrafo es traducción literal de un discurso del fundador de los illuminati de Baviera y que Barruel lo copia, precisamente, para denunciar a ilustrados y masones por sus «blasphèmes contre l'amour de la patrie ${ }^{70}$. Es, por tanto, una crítica al cosmopolitismo ilustrado, similar a las de algunos reaccionarios españoles que acusaron a la "filosofía» de apagar el «amor indeleble» debido a la "patria $»^{71}$.

Álvarez Junco cita también unas palabras del «Filósofo Rancio», Francisco Alvarado: «iPor dónde se nos ha aparecido [...] esta nación a la que ahora se cuelga la soberanía?». En realidad, basta leer el texto del que estas palabras provienen para advertir que, lejos de negar la realidad nacional, Alvarado sostiene que los hombres no se reúnen «todos juntos, sino en tantas porciones cuantas han sido y son las naciones independientes». De hecho, el «Filósofo Rancio» atribuye a esas naciones «la soberanía nacional en virtud de la cual eligieron un gobierno» ${ }^{72}$. Lo que Alvarado combate no es la idea de nación, sino la concepción abstracta - desnacionalizada - del pacto social. Sus reflexiones no están lejos de las de otros reaccionarios europeos. De Maistre, por ejemplo, había dicho: "J'ai vu, dans ma vie, des François, des Italiens, des Russes, etc. [...] mais quant à l'homme, je déclare ne l'avoir recontré de ma vie» ${ }^{73}$.

Yo solo he hallado dos textos «serviles» que, hacia el final de la guerra, muestran cierto rechazo al uso del término «nación» en «sentido filosófico y espíritu republicano ${ }^{74}$. Uno de ellos lamenta que, tras la declaración de la soberanía nacional, el grito de los espańoles hubiera dejado de ser unánime: «Los buenos españoles continuaron y continúan clamando: viva el rey; pero

69 Diario de las discusiones y actas de las Cortes, 25-8-1811, p. 19.

70 Barruel (1798): III, 184 y 274.

71 Larrea (2006b): 78.

72 Alvarado (1813b): 9.

73 De Maistre (1797): 102.

74 López de Ulloa (1813a): 4; López de Ulloa (1813b): 6, y El Procurador general de la nación y del rey, 25-2-1813, p. 1213. 
algunos de la isla y de Cádiz gritaron: viva la nación» ${ }^{75}$. A la prensa liberal le extrańaron estas palabras por considerar que el grito "viva la nación» no había suscitado suspicacias ni siquiera en la época en que «se hallaban ignorados o confundidos los derechos del pueblo ${ }^{76}$. Y lo cierto es que, en otros textos reaccionarios, el grito "viva el rey» convive sin problemas con «viva la nación $»{ }^{77}$

Actualmente, hay numerosas ediciones digitales de obras «serviles» en las que es posible realizar búsquedas por palabras dentro del texto. Cualquiera puede, por tanto, comprobar fácilmente que los reaccionarios empleaban con profusión los términos «nación», "patria»y «pueblo», y que ni siquiera preferían "patria» a «nación». De hecho, en varios de los más relevantes escritos serviles, «nación» aparece más del triple de veces que «patria» ${ }^{78}$.

Basándose en el catálogo de la Biblioteca Nacional y en la aplicación informática Google Ngram Viewer, Juan Francisco Fuentes ha mostrado que el uso escrito de la palabra "nación» se disparó durante la Guerra de la Independencia y el Trienio Constitucional y se desplomó tras las restauraciones de 1814 y 1823. Pienso, no obstante, que Fuentes se equivoca al esgrimir este auge del término «nación» en épocas revolucionarias —observable también en el Sexenio Democrático - como prueba de que los reaccionarios no lo aceptaron plenamente hasta las últimas décadas del siglo $\operatorname{XIX}^{79}$. De hecho, según el catálogo de la Biblioteca Nacional, las obras en cuyo título figura el término «nación» no fueron más habituales en la Restauración canovista que en tiempos del absolutismo fernandino. Y, según Ngram Viewer, la palabra «nación» aparece más regularmente en los escritos de 1816 o 1830 que en los de 1898. Por otra parte, el catálogo de la Biblioteca Nacional evidencia que la edición de obras con «nación» en el título fue mucho más frecuente en la Guerra de la Independencia que en cualquier otra época de la España contemporánea, incluyendo el Trienio Liberal y el franquismo. Diríase que la guerra contra el Imperio francés afectó al auge del término «nación» más que las revoluciones liberales o el «nacionalcatolicismo».

Sin duda, en 1814 los conservadores adaptaron su lenguaje a las exigencias de la restauración fernandina, igual que en 1808 lo habían adaptado al momento de fervor patriótico que atravesaba España. En cualquier caso, las fuentes evidencian que, en su combate contra los liberales, los «serviles»

\footnotetext{
El Procurador general de la nación y del rey, 25-II-1813, p. 1213.

Aurora patriótica mallorquina, 30-9-1813, p. 113.

Menéndez Luarca (1794): cliii, y La lealtad en triunfo (1814).

78 Freire Castrillón (1809); Lardizábal (1811); Aviso importante (1811), y F. A. y B. (1813).

79 Fuentes (2013): 179-180 y 192.
} 
emplearon continuamente la palabra nación, si bien muchos la entendieron como una unión de estamentos y provincias encabezada por el rey.

Es más, aunque entre los reaccionarios abundasen los provincialistas, algunos se inclinaron por reforzar la unidad nacional. Y no me refiero a quienes insistían en reestablecer Inquisición para hacer de España «un solo pueblo; tierra de un solo labio, idioma, e ideas ${ }^{80}$. Hablo, más bien, de los que, como José Clemente Carnicero, promovieron que los españoles, «sin atender a más fueros ni rivalidades», hablasen "una misma lengua» y tuvieran «unas mismas leyes, y hasta unos mismos pesos y medidas» ${ }^{81}$. Así, por ejemplo, el obispo de Urgell, que luego firmaría la polémica Instrucción pastoral contra el liberalismo gaditano, aconsejaba en 1809 aplicar un único código legal «no a reinos y provincias, sino a un reino solo y unido de ellas, no a muchas coronas, sino a una, ni a muchas familias, sino a la de España y acomodarlo en cuerpo y alma al carácter de la nación ${ }^{82}$.

Álvarez Junco cree que a los «serviles» les disgustaba el concepto nación por lo que «tenía de fortalecedor del poder del Estado». Sin embargo, él mismo afirma que el «nacionalcatolicismo", aun en tiempos de Franco, tuvo siempre un «lastre antiestatal» ${ }^{83}$. A este respecto, por tanto, las diferencias entre «serviles» $\mathrm{y}$ «nacionalcatólicos» no están claras.

\section{PATRIA}

Más que a la palabra «nación», los reaccionarios mostraron cierta resistencia al "nuevo término patriota», asociado con frecuencia a ilustrados y liberales. Asimismo, algunos preferían rancias expresiones como "amor a la patria» frente a neologismos dieciochescos como "patriotismo». Pero, por más que se opusieran a "la moderna patria republicana», siempre insistieron en su lealtad a la «verdadera patria». Para ellos, el «verdadero amor a la patria» era el de los "espańolazos antiguos» y no el de los liberales, que hablaban de la patria como si fuese «la primera de las divinidades» pero, en la práctica, ansiaban entregarla a sus enemigos y extinguir «todas las costumbres espańolas» ${ }^{84}$.

\footnotetext{
Traggia (1812): 194.

Carnicero (1813): I, viii.

Artola (1976): II, 222.

Álvarez Junco (2001): 357 y 461.

4 Vaca de Guzmán (1785): 35; Diccionario razonado (1811): 52-55; Alvarado (1812a): 25; El Sensato, 2-2-1812, pp. 333-336, y Thiulen (1813): 20-21.
} 
Los «serviles» rechazaban el patriotismo «filosófico» que relegaba la religión a un segundo plano. En 1811, un escrito antiliberal clamaba contra «esos proyectos gentílicos, esas canciones patrióticas» que invitaban a «morir por la patria" como si la patria pudiese "socorrer al soldado en el trance o después de la muerte». Pero ese mismo escrito celebraba el «espíritu de patriotismo y unión» que había triunfado en 1808 gracias a los «sentimientos de la religión ${ }^{85}$. Y otros muchos llamaban a amar «ciegamente a nuestra patria hasta la locura» y a morir en "defensa de la patria, de la religión y de nuestro amado Fernando» ${ }^{86}$. El muy «servil» Blas Ostolaza predicó un sermón alentando a los españoles a "morir con honor» antes que aceptar la "servidumbre infame» que amenazaba a la patria. Ostolaza no dudó en exhortar al "entusiasmo por la independencia» y al "amor a la patria», entendida como conjunto "de nuestros semejantes, unido para la mutua defensa por el vínculo de unas mismas leyes» y como «madre común, a la que debemos la existencia y todo lo que somos ${ }^{87}$. En vísperas del regreso de Fernando VII, el Procurador general de la nación y del rey explicó qué significaba el grito «viva la patria»: «Decididos estamos a morir, y a derramar hasta la última gota de nuestra sangre por no dejar de ser lo que somos, por no dejar de ser españoles» ${ }^{88}$.

Los reaccionarios tenían claro que la religión era más importante que la patria $^{89}$. Simón López dijo expresamente en las Cortes: «Antes es la religión que la patria, y sin religión la patria no vale nada $»^{90}$. ¿Pero acaso habrían dicho otra cosa Balmes o Menéndez Pelayo?

Se ha dicho que, en esos ańos, la palabra "patria» «figuraba al final de la triada absolutista", pero lo cierto es que no había un orden establecido ${ }^{91}$. Según el Procurador general, el pueblo gritaba «viva la religión, viva la patria, viva Fernando» $»^{92}$. Otras fuentes dicen incluso «patria, rey y religión» 0 «patria, religión y rey ${ }^{93}$. El orden importaba poco porque, en el discurso servil, estas palabras

85 Espiritu irreligioso (1811): 12, 16.

86 Giralt (1809); Freire Castrillón (1809): 12-16, y Carnicero (1813): V, 93.

87 Ostolaza (1811a): 16, 17, 20, 33 y 35.

88 Apéndice al Procurador general de la nación y del rey, 19-3-1814, p. 79.

89 Vélez (1812): 103, y Alvarado (1812a): 29.

90 Diario de las discusiones y actas de las Cortes, 15-1-1811, p. 120.

91 Rubio Pobes (2014): 120.

92 El Procurador general de la nación y del rey, 16-1-1814, p. 3, y Apéndice al Procurador general de la nación y del rey, 19-3-1814, p. 78.

93 Junta de Gobierno de Cádiz (1809); Gutiérrez y Polop (1809): 16, y Carnicero (1813): III, 158 y VIII, 89. 
«siendo tres se convierten en una»" ${ }^{94}$. Si los antiliberales gritaban «viva Espańa» era por considerar que «esta preciosa palabra envolvía en sí a su religión y a su monarca, sobre que diciendo viva España, de una vez decían viva el catolicismo, viva Fernando" ${ }^{95}$. Los franceses, según Alvarado, habían pecado contra la patria, «mas también contra todas y cada una de las cosas que encierra esta palabra: contra el Dios, contra la religión, contra el rey, contra la legislación, contra la libertad, contra las propiedades, contra el total y contra cada uno de los hijos de la patria ${ }^{96}$.

Los «serviles» juzgaban indisolublemente «unida la defensa de nuestra santa religión católica con la justísima causa de nuestro rey, y de nuestra libertad, patria y vidas» ${ }^{97}$. Por eso no dudaron en sostener, con sus sermones y escritos, «la justa causa de la nación y el rey»" ${ }^{98}$ A sus ojos, solo la religión podía suscitar la «unión, patriotismo y energía» necesarios "para conseguir la libertad e independencia de la nación»" ${ }^{9}$. La religión inspiraba "el amor de la nación» y, a la inversa, el «entusiasmo patriótico» sostenía el combate "por nuestra religión, nuestra independencia y por el rey que Dios nos ha dado» ${ }^{100}$.

"No hay casi enemigo de la patria que no comience o no acabe por enemigo de la religión», escribió Alvarado en $1810^{101}$. Para los reaccionarios, la fidelidad a la patria obligaba a los españoles a rechazar todo aquello que jamás se había «sufrido» en España ${ }^{102}$. Y, puesto que el "corazón español» se distinguía, ante todo, por su intransigente adhesión al catolicismo, quien atacara la unidad religiosa debía ser mirado como «mal espańol» y castigado como reo de «lesa nación ${ }^{103}$. De ahí que el mero intento de introducir las ideas de Voltaire, Rousseau y compañía se viera como una auténtica «invasión» que venía a completar la ofensiva napoleónica contra "nuestra religión e independencia» ${ }^{104}$. Porque, si esas ideas se toleraban, «dejaríamos de ser españoles y católicos»" ${ }^{105}$.

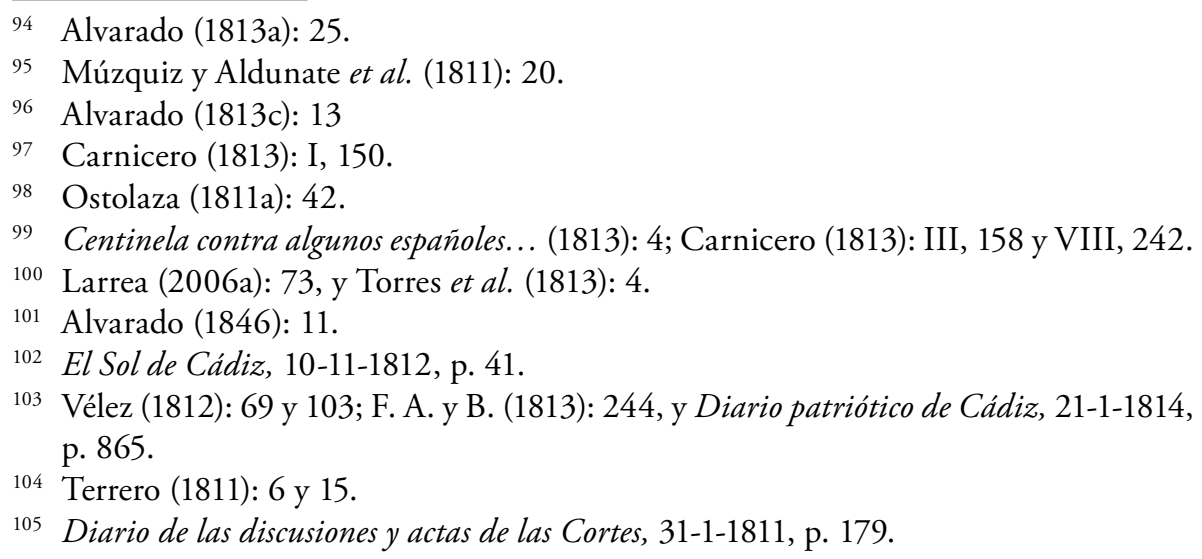


En prueba del escaso patriotismo «servil», varios autores citan esta frase de fray Manuel Amado sobre 1808: "No fue cuanto hicimos a favor de nuestra patria; obramos porque la religión exigía de nosotros que obrásemos de ese modo». En realidad, al decir esto, Amado solo pretendía argumentar que el «heroico pueblo» no había rechazado la «invasión de Napoleón» por atender a los intereses materiales de la patria, sino por un sentimiento religioso que lo empujaba a «arrojar lejos del Pirineo» a los «tiranos» que pretendían «subyugar» a Espańa y acabar con «nuestra libertad». Porque en España que según Amado no era "como las demás naciones»— solo la fidelidad religiosa podía inclinar la balanza de la historia «a favor de la nación». Para este autor, los liberales de Cádiz «no eran la nación» y, por el contrario, los clérigos — acostumbrados a servir «en todos tiempos a la patria»— habían contribuido "cual nadie a nuestra resistencia y triunfo»" ${ }^{106}$. No parece que Amado admitiera «paladinamente lo que hubo de impostura en el furor patriótico del absolutismo en guerra ${ }^{107}$. Simplemente repitió lo que antes dijeron muchos «serviles»: que el rasgo esencial de los espańoles era su voluntad de "perderlo todo antes que la fe católica» ${ }^{108}$. Con esto no pretendían negar el patriotismo de 1808, sino celebrar que el pueblo de España hubiera «sabido enlazar con estrecho y fuertísimo [sic] vínculo» el amor a la religión y el amor a la patria $^{109}$.

\section{PUEBLO}

Según Mater dolorosa, el «temor al pueblo» de los primeros reaccionarios españoles los llevó a recelar de la intervención popular en la insurrección de 1808 y les impidió identificarse con el pueblo, como sí harían, décadas más tarde, los conservadores románticos ${ }^{110}$. Lo cierto es, sin embargo, que los «serviles» se presentaron desde el principio como representantes del «pueblo de España», un pueblo al que creían "tan servil» como ellos mismos ${ }^{111}$. Adoptando burlonamente el lenguaje de sus enemigos, los reaccionarios alabaron con frecuencia el "celo servilón de la masa de nuestro pueblo», dispuesto a dar

106 Amado (1831): III, 238-261.

107 Fuentes (2013): 179.

108 Cerezo (1811): 32.

109 Discusión del proyecto (1813): 283.

110 Álvarez Junco (2001): 141-142.

111 Apéndice al Procurador general de la nación y del rey, 20-3-1814, p. 81, y F. A. y B. (1813): 10 . 
la vida por «defender la religión, verdadera superstición y fanatismo heredado de sus padres y apreciado como el patrimonio más pingüe» ${ }^{112}$.

A medida que el enfrentamiento político se iba centrando en torno a la Inquisición, los «serviles» se mostraron más y más seguros de que el pueblo estaba de su parte y deseaba revertir las políticas liberales. En sus discursos, encomiaron una y otra vez «la religiosidad del pueblo espańol» y acusaron a los diputados liberales de contrariar la «voluntad general», la «voluntad de la nación», la "voluntad del pueblo», el "clamor universal de todos los españoles» o el «voto uniforme de la nación» ${ }^{113}$. No faltó quien recordase a esos diputados que, como "representantes de un pueblo supersticioso" y "poco ilustrado", debían «seguir la superstición del pueblo» condescendiendo con «la voluntad o preocupación general» ${ }^{114}$. Los «serviles» insistieron en que la nación no la formaban unos pocos filósofos «amantes de la novedad», sino varios millones de españoles poco o nada "dispuestos a tanta ilustración»" ${ }^{115}$. Según esto, la «nación entera» aborrecía el liberalismo, y las ideas de «dos docenas de impíos» no podían prevalecer «contra el poderoso clamor de más de nueve millones de almas $»^{116}$.

Cuando, a finales de 1813, se reunieron las Cortes ordinarias, los «serviles» exhortaron a los nuevos diputados a representar más fielmente a «una nación católica que reclama sus créditos menguados por la tanta filosofía que se manifestó en las Cortes extraordinarias»"17. A comienzos de 1814, el Procurador general — que se decía resuelto a no apartarse «jamás de la voluntad de la nación»- celebró que las Cortes empezaran a «ceder a la imperiosa ley del pueblo, justamente resentido de sus designios revolucionarios». Aun así, amenazó a los diputados: «Si no os conducís del modo conforme a la voluntad general de la nación, vosotros mismos os labráis vuestro exterminio»" ${ }^{118}$. Por las mismas fechas, un diputado «servil» advirtió que, si esas Cortes no corregían el rumbo liberal de las anteriores y se plegaban a la «indudable general voluntad» de la «masa nacional», el "pueblo heroico, generoso y noble» acabaría

112 F. A. y B. (1813): 82.

113 Discusión del proyecto (1813): 75, 126, 233 y 398; Alvarado (1846): 123; El Procurador general de la nación y del rey, 24-2-1813, p. 1202, y Atalaya de la Mancha, 20-71813 , p. 21.

114 Alvarado (1811): 29; El Cristiano Viejo (1813): 39, y Discusión del proyecto (1813): 235.

115 Discusión del proyecto (1813): 234.

116 Atalaya de la Mancha, 20-7-1813, p. 21; El Procurador general de la nación y del rey, 15-12-1812, p. 612, y Decreto definitivo (1813): 28.

117 El Cristiano Viejo (1813): 3.

118 El Procurador general de la nación y del rey, 15-12-1812, p. 620 y 16-1-1814, pp. 1-3. 
pidiendo al rey que las disolviera ${ }^{119}$. Más tarde, cuando el rey las disolvió, los reaccionarios lo celebraron como un triunfo de «la voluntad general de la nación que detestaba el nuevo orden de cosas»" ${ }^{120}$. Desde la perspectiva "servil», el alborozo popular por la restauración de 1814 demostraba que los liberales habían fracaso en su intento de «filosofizar» la nación ${ }^{121}$.

Los mismos liberales acusaron con frecuencia a los «serviles» de «hacer del pueblo un instrumento ciego de sus caprichos», inflamar «los ánimos de la multitud» e instigar "una revolución popular» contra las «legítimas autoridades ${ }^{122}$. Los reaccionarios, por su parte, lamentaron que los liberales se empeńasen en «rectificar la opinión del pueblo español», apagando mediante la filosofía «el fuego devorador» que ardía «en el corazón de la España» ${ }^{123}$.

Los antiliberales insistieron también en que la resistencia a la invasión francesa se había debido a los «arraigados principios de barbarie» del pueblo español y no a las «lecciones filosóficas» de sus «ilustrados políticos y legisladores ${ }^{124}$. Según el relato reaccionario, los levantamientos antinapoleónicos demostraron que - a pesar del afrancesamiento de las élites - el pueblo conservaba «el carácter y virtudes nacionales» y ansiaba purificar a España de la «afeminación y corrupción» en que la habían sumido unos ministros dispuestos a cambiar "el evangelio por la filosofía»" ${ }^{125}$. "La masa de nuestra nación era y es española: eso nos ha salvado", escribió Manuel Freire Castrillón en $1808^{126}$. Y el «Filósofo de Antaño» afirmó que, en la «revolución» española, Dios mismo «habló infinitas veces por boca del pueblo de España, y depositó el poder en su brazo» ${ }^{127}$.

Los reaccionarios no se cansaron de repetir que «solo el pueblo, ese pueblo anti-liberal, iluso y supersticioso", guiado por sus "clérigos y frailes ignorantes», había dado la cara en los "primeros días de horror y de peligro» ${ }^{128}$.

119 Diario patriótico de Cádiz, 15-1-1814, pp. 794-795.

120 Larrea (2006c): 91.

121 El Procurador general del rey y de la nación, 24-12-1814, p. 1440.

122 Discusión del proyecto (1813): 368; La Antorcha, 1813, I, pp. 3 y 5, y El Tribuno del pueblo español, 4-6-1813, pp. 89.

123 Alvarado (1812c): 6 y 31, y F. A. y B. (1813): 82.

124 Historia sucinta (1811): 3, y Espiritu irreligioso (1811): 14.

125 Diario patriótico de Cádiz, 15-1-1814, p. 794, y Alvarado (1811): 49-50.

126 Freire Castrillón (1809): 10.

127 F. A. y B. (1813): 294.

128 Traggia (1811): 22; Espíritu irreligioso (1811): 14; Vélez (1812): 114 y 126; Alvarado (1812a): 47 y 48; Alvarado (1812c): 31; Decreto definitivo (1813): 18; El Cristiano Viejo (1813): 39, y F. A. y B. (1813): 82. 
Algunos, como Alvarado, incluso reclamaron mayores derechos políticos para ese «pueblo español» que en 1808 se había convertido en el «restaurador de la monarquía $»^{129}$.

\section{GLORIAS DE ESPAÑA}

Los conservadores españoles presentaron la intervención napoleónica de 1808 como una ocasión providencial para que «la nación española» recobrara la "grandeza» que había tenido hasta "finales del siglo XVII». Esta antigua grandeza la atribuían sobre todo a los "héroes de la España» que habían "purgado» el país de arrianos, judíos, moriscos y herejes ${ }^{130}$. Ensalzaron, en especial, al «santo rey Recaredo» — padre de «la ley suprema de nuestra santa y religiosa intolerancia»—; a Pelayo — que suscitó en "los corazones españoles» el "proyecto de reconquistar de los moros toda la España»—, y a los Reyes Católicos, fundadores de la Inquisición y «los más grandes soberanos de nuestra España» ${ }^{131}$.

Los reaccionarios recurrieron con frecuencia a las «luces de la historia de nuestra nación» para reivindicar «nuestra gloria nacional» frente a las críticas ilustradas. Y celebraron la «antigua legislación» española — que, a su entender, podía "eternamente servir de modelo a las naciones» — para deslustrar, por comparación, las reformas liberales ${ }^{132}$. En particular, defendieron la intolerancia religiosa que creían consustancial a España desde los reyes godos. Según ellos, «nuestros antiguos anales» mostraban a las claras la insalvable distancia entre los «sentimientos de nuestros mayores» y los de «los filósofos modernos». En los concilios de Toledo, el Fuero Juzgo, la Reconquista, las Partidas, las expulsiones de judíos y moriscos y muchos otros vestigios de la intolerancia española hallaban irrefutables testimonios contra los empeńos liberales por convertir la «Espańa católica en Babilonia confusa» ${ }^{133}$.

Los reaccionarios llamaron a volver la atención «sobre nuestras cosas, antes disipada con el embeleso de extrañas, y lisonjeras novelerías de la Francia». En sus escritos, exhortaron a los españoles a estudiar el pasado de su patria

129 Múzquiz y Aldunate et al. (1811): 17; Carnicero (1813): III, 148, y Alvarado (1846): 156.

130 De Jesús (1809): 8; López de Ulloa (1813a), y Gutiérrez y Polop (1809): 9, 10 y 27.

131 De Jesús (1809): 11; Torres et al. (1813): 3; Discusión del proyecto (1813): 147, y Artola (1976): II, 202.

132 F. A. y B. (1813): 306-307.

133 Cerezo (1811): 32-37; F. A. y B. (1813): 306-307. 
si no querían ser "extranjeros en su propio país» y acusaron a los sabios «a la francesa» de haber desfigurado a "nuestros reyes, personajes, y sucesos históricos» y arrinconado a "nuestros mejores escritores del siglo de oro» ${ }^{134}$. Algunos situaron el paraíso nacional perdido en tiempos de los godos, considerando que nunca fue «la monarquía más gloriosa que entonces» y que «la Iglesia de España fue en aquella época la más santa y la más feliz que había en oriente y occidente ${ }^{135}$. Pero, entre los apologistas de la Inquisición, fueron los «tiempos de Isabel, de Carlos V y de Felipe II» — tiempos «en que la Inquisición y el sacerdocio estaban en su auge» - los más celebrados como unos siglos "verdaderamente de oro» en los que España había producido decenas de "grandes hombres» para asombro del «orbe todo». Los reaccionarios elogiaron a Felipe II por los mismos motivos por los que los liberales lo reprobaban: por ser el más "fanático» y el «más aferrado servilón entre las majestades católicas» ${ }^{136}$.

De este «siglo de oro para la España», los reaccionarios rescataron también a Cisneros, a «los sabios españoles del Concilio de Trento» y, en general, a «los teólogos y doctores españoles que fueron el honor de España y de su siglo en todo género de literatura» ${ }^{137}$. Según el relato «servil», los «Zuritas, Marianas, Cisneros, Granadas» y otros «sabios y piadosos» españoles de entonces demostraban de qué era "capaz una nación que no admite el sistema liberal ${ }^{138}$.

Alvarado presumía de decir «lo mismo que se ha pensado y dicho siempre en España por toda la nación», a excepción de Juan Padilla y "pocos otros sediciosos». Según esto, sus ideas coincidían en todo con las que tiempo atrás habían expresado Isidoro, Leandro, Ildefonso, Vitoria, Suárez «y otro millón de teólogos», Mariana, Zurita y "todo el resto de los historiadores», Cervantes, Quevedo, Lope de Vega, Saavedra Fajardo y una «turbamulta de filósofos (rancios se supone), humanistas, y poetas ${ }^{139}$.

\section{LA ANTIESPAÑA}

Cree Álvarez Junco que los «serviles» habrían podido «explotar la idea de que ellos eran los "verdaderos españoles" " para "expulsar a los liberales fuera

134 Historia sucinta (1811): 2; Freire Castrillón (1809): 9, y Hermida (1812): 43.

135 Cerezo (1811): 37.

136 Centinela contra algunos (1813): 13; Sanz (1812): 64; Traggia (1812): 189, y F. A. y B. (1813): 88 y 135-139.

137 Artola (1976): II, 204, y Decreto definitivo (1813): 24.

138 Ostolaza (1811b): 8 y 13; F. A. y B. (1813): 57, y Mon y Velarde et al. (1814): 40

139 Alvarado (1813c): 40. 
de la comunidad imaginaria»; pero que, en lugar de eso, presentaron su lucha como un combate universal entre el catolicismo y la impiedad, dejando así «la nación en manos de los liberales» ${ }^{140}$.

Lo cierto es que, en sus escritos, los «serviles» sí se presentan como los «verdaderos españoles», los «españoles legítimos» que defienden el «lenguaje y las máximas de toda la nación espańola» y quieren "en todo y siempre ser españoles» ${ }^{141}$. Convencidos de que quien no comparte sus ideas «no es español, ni puede serlo», se niegan a "mirar como españoles» a sus adversarios, aunque "por equivocación» hayan nacido en España ${ }^{142}$. Por eso insisten en que los partidarios de José Bonaparte «no son españoles», y pintan a los «filósofos liberales de Cádiz» como "apóstatas de la religión, y de la nación», «falsos españoles», «españoles espurios», «desnaturalizados españoles», «indignos del nombre español» $y$ «traidores a la patria» ${ }^{143}$. En el discurso reaccionario, los defensores del "galicismo liberal» son "los franceses mismos», pues calcan «sus ideas, sus discursos, sus proyectos, sus deseos [...] su religión, su política, su moral [...] su vida, su conversación, y hasta su vestido» ${ }^{144}$.

Según el relato «servil», en los «primeros años de nuestra gloriosa revolución» los «liberales ilustrados», lejos de contribuir «a la expulsión de los enemigos», fueron "prosélitos, adoradores, o íntimos aliados» de los afrancesados. Contagiados como ellos del «espíritu francés», tuvieron por «bárbara temeridad el movimiento popular» del "memorable 2 de mayo» e hincaron la rodilla «ante su adorado Pepito». Tras los insospechados éxitos de la «resistencia del pueblo», los liberales cambiaron de estrategia e intentaron continuar mediante escritos contra las «principales características y máximas» de la nación española- el "plan político y religioso que empezaron los franceses» ${ }^{145}$. Más adelante, disfrazados de patriotas pero muy alejados del sentir «de

140 Álvarez Junco (2001): 345.

${ }_{141}$ Aviso importante (1811): 41 y 53; Diccionario razonado (1811): 67; El Cristiano Viejo (1813): 45, y El Procurador general de la nación y del rey, 16-1-1814, pp. 1-3.

142 Diccionario manual (1811); Traggia (1812):186, y Diario patriótico de Cádiz, 28-I1814 , p. 844.

143 Múzquiz y Aldunate et al. (1811): 1; F. A. y B. (1813): 55 y 173; Centinela contra algunos (1813): 6; Los Guerrilleros por la religión, la patria y el rey, 14-3-1813, p. 4; Diario de las discusiones y actas de las Cortes, 6-6-1811, p. 195; Sanz (1812): 96, y Centinela de la patria en Reus, 1-4-1814, p. 1.

144 F. A. y B. (1813): 84 y 269-270.

145 Vélez (1812): 126; F. A. y B. (1813): 271; Decreto definitivo (1813): 18 y 21; Diccionario razonado (1811): 40 y 54; El Sensato, 12-12-1811, p. 282; Semanario cristiano-politico de Mallorca, 31-12-1812, pp. 269-274; Los Guerrilleros por la religión, la patria y el rey, 13-III-1813, p. 4, y Diario patriótico de Cádiz, 13-1-1814, p. 780 y 22-1-1814, p. 852. 
lo general de la nación», fueron a Cádiz a «renovar la faz de la España»según los «malignos principios» del «filosofismo flamante de la ilustración». Así, mancillando el «antiguo esplendor» de España, pretendían someterla, sin necesidad de ejércitos, a la "total dominación extranjera»"

Desde la perspectiva «servil», el liberalismo era un «hijo bastardo» de la nación que se disfrazaba de "amor a la patria» para introducir ideas y costumbres "cada vez más antiespañolas»" ${ }^{147}$. Estas ideas y costumbres nunca se habrían difundido al sur de los Pirineos «si en España todos fuesen españoles, y si por desgracia no hubiesen nacido tantos franceses, tantos filósofos en España $»^{148}$. Por eso, los "españoles rancios», decididos a «obrar a la española» y sin la menor sombra de «francesismo», llamaron a «limpiar» a Espańa de liberales, como antańo se «limpió de judíos», para que sus habitantes volvieran a ser «todos españoles» ${ }^{149}$.

Los reaccionarios presentaron a los liberales como herederos de los «filósofos a la francesa» que, empujados por su "galomanía», llevaban un siglo empeñados en "pervertirnos y trastornar nuestras costumbres antiguas y graves, que dieron en otro tiempo tanta gloria al nombre español ${ }^{150}$. Según el relato reaccionario, el «espíritu gálico» ahogaba España desde que Luis XIV y Felipe V quisieron que no hubiera "ya más Pirineos» y las élites españolas cayeron en un "frenesí gálico» que fue degradando la lengua, las ideas y las costumbres españolas hasta que Godoy y sus acólitos dejaron a España «postrada ante el trono de su mayor enemiga ${ }^{151}$. Los reaccionarios no solo arremetieron contra el «patriarca liberal» Godoy y el «aborrecido» Carlos IV, sino también contra la «política antirreligiosa» de Aranda, Campomanes, Floridablanca, Urquijo y otros ministros iniciados en «los misterios de la filosofía» que —además de domar el «fiero carácter nacional» con su despotismohabían expulsado a los jesuitas, ahogado a la Inquisición e impulsado otras muchas medidas para difundir «la ilustración liberal» a «imitación de los franceses» y completar así la «gran mudanza de la nación» ${ }^{152}$. Si con Felipe V «se

146 Historia sucinta (1811): 4; El sensato, 2-1-1812, pp. 336 y 337; Los Guerrilleros por la religión, la patria y el rey, 13-III-1813, p. 4; El Procurador general de la nación y del rey, 23-12-1812, p 675 y 24-2-1813, p. 1.203, y Diario patriótico de Cádiz, 13-1-1814, p. 780.

147 El Sensato, 2-2-1812, p. 337, y López de Ulloa (1813c): 3 y 5.

148 Torres et al. (1813): 3 .

149 Alvarado (1811): 50; El Sensato, 2-2-1812, pp. 229-337, y Apéndice al procurador general de la nación y del rey, 19-3-1814, p. 85.

150 Ostolaza (1811b): 8 y 21.

151 Freire Castrillón (1809): 7; Historia sucinta (1811): 2-3, y Vélez (1812): 66-67.

152 Freire Castrillón (1809): 17; Alvarado (1811): 49-50; Vélez (1812): 110 y 159-160; F. A. y B. (1813): 49-64, 107, 110 y 307, y Decreto definitivo (1813): 4-7. 
allanaron los Pirineos», los «serviles» querían subir «los Pirineos a las estrellas» para que a España no volviese a dominarla «jamás la Francia ni su filosofía ${ }^{153}$.

La excepcional situación política creada por las abdicaciones de Bayona permitió a los antiilustrados españoles expresar más radicalmente su rechazo a la «francomanía» de la Espańa dieciochesca y atribuirla directamente al reformismo borbónico ${ }^{154}$. El «tenebroso siglo de la pseudo-filosofía que hemos llamado ilustrado" se convirtió así, de una vez por todas, en el siglo antiespañol, un periodo de letargo nacional del que «el león de España» no habría despertado hasta $1808^{155}$.

\section{IDENTIDAD NACIONAL}

Para Álvarez Junco, el estallido de xenofobia antifrancesa en la España de 1808 poco tuvo que ver con el «patriotismo positivo, de exaltación de la propia identidad», asociado a los nacionalismos modernos ${ }^{156}$. Lo cierto es, sin embargo, que los ataques a la "Francia filósofa» fueron casi siempre unidos a la exaltación de la «muy católica» España ${ }^{157}$. Desde el principio, la guerra se presentó como una lucha entre identidades opuestas: el «frivolismo francés» frente al «tesón y la solidez española»; la «Francia cismática, tolerante, anti-cristiana» frente a la «nación católica por excelencia»; la «turba de viles ateos» frente al "pueblo de Dios», escogido «entre todas las naciones» para combatir el error; los «impíos franceses», «amigos de la novedad» y de los «ilustrados filósofos», frente a los españoles, católicos "por naturaleza» y «hasta los tuétanos» $\mathrm{y}$ 《acérrimos defensores de las tradiciones y costumbres de sus mayores ${ }^{158}$.

Según el discurso «servil», mientras el pueblo ansiaba "volver a ser español» y luchaba por mantener su «carácter nacional», una minoría de «afrancesados o afilosofados» trataba de «extraviar la voluntad de la nación, y sacarla

153 Vélez (1812): 59; López (1809): 29, y El Procurador general de la nación y del rey, 24-21813, p. 1205.

154 Decreto definitivo (1813): 4-7.

155 Freire Castrillón (1809): 9, y Vélez (1812): 84.

156 Álvarez Junco (1994): 80, 89-91.

157 López (1809): 29.

158 Diario político de Mallorca, 30-VI-1808, p. 62; El Patriota compostelano, 21-7-1809, pp. 21-24; Gutiérrez y Polop (1809): 9; López (1809): 19; Espíritu irreligioso (1811): 11; Ostolaza (1811b):16; Decreto definitivo (1813): 2; Discusión del proyecto (1813): 68; El Cristiano Viejo (1813): 45; Los Guerrilleros por la religión, la patria y el rey, 14-31813, p. 4, y F. A. y B. (1813): 294. 
de sus máximas y principios» ${ }^{159}$. Esta "caterva de falsos filósofos» quería que España — «la más católica y religiosa de todas las naciones»— se volviera «semejante a la Francia» ${ }^{160}$. Aspiraba a introducir «el filosofismo flamante de la ilustración» para «debilitar el antiguo carácter de la nación» y «entibiar el entusiasmo del pueblo español ${ }^{161}$. Pero sus esfuerzos se estrellaban contra la «fanática y supersticiosa» España que, fiel a «la majestad de su carácter», se empeñaba en "desviar de sí a todos los novadores», empezando por la «nueva secta liberal ${ }^{162}$.

Los reaccionarios temían sobre todo que se introdujese en «la religiosa España» una «libertad de pensar, y tolerancia de todas las sectas» incompatible con el «carácter español», siempre firme «en el odio implacable a toda novedad contraria a su religión santa ${ }^{163}$. Pero confiaban en que Dios sostendría "la empresa y causa de la nación española» como lo había hecho en el pasado, cuando arrianos, judíos, musulmanes y otros «maestros de la impiedad y el error» cedieron «a la firmeza de los discípulos de Santiago»" ${ }^{164}$.

Los «serviles» aceptaban con gusto los «honrosos epítetos de fanáticos, supersticiosos y otros semejantes» y celebraban que «español e intolerante» fueran «nombres sinónimos» ${ }^{165}$. España era, a sus ojos, «una nación que debe su felicidad a su intolerancia ${ }^{166}$. Así se habría demostrado, por enésima vez, en 1808, cuando el «feliz goticismo, barbarie y fanatismo español» impidió el triunfo napoleónico, demostrando que la «unidad religiosa» hacía a España «inconquistable» ${ }^{167}$. Los «serviles» no dudaron en alabar «nuestra ignorancia y nuestras tinieblas» y exhortaron a sus lectores a perpetuar la "barbarie» que hacía de España una nación "servil, ignorante, fanática y supersticiosa»" ${ }^{168}$. Por eso, de entre las muchas afrentas liberales al «espíritu verdaderamente español», condenaron sobre todo la abolición del Santo Oficio, tribunal «que toda

159 Diario de Santiago, 1-6-1808, p. 3 y 5-8-1808, p. 257; López (1809): 47, y Diario Patriótico de Cádiz, 26-1-1814, p. 881.

160 Diccionario razonado (1811): 28; Discusión del proyecto (1813): 308, y El Procurador general de la nación y del rey, 24-3-1813, p. 1205.

161 Historia sucinta (1811): 4; Vélez (1812): 133, y Larrea (1814).

162 F. A. y B. (1813): 259 y Apología de la Inquisición (1811): 15.

163 El Observador politico y militar de España, 15-7-1809, pp. 10-11; El Procurador general de la nación y del rey, 23-12-1812, p. 674.

164 De Jesús (1809): 11; Carnicero (1813): I, vii.

165 Sidro Vilarroig (1813): 9.

166 Aldao y Castro (1814): 46.

167 Freire Castrillón (1809): 12; Artola (1976): II, 202.

168 Diccionario razonado (1811): 6; Los crimenes constitucionales (1811): v; F. A. y B. (1813): 54, y Discusión del proyecto (1813): 235. 
la nación venera» y cuya extinción creían una «infidencia general contra la nación» y "contra su celoso carácter»" ${ }^{169}$. Desde la óptica «servil», para que hubiese de nuevo «una sola familia de españoles puros y castizos», era preciso reestablecer la Inquisición y perseguir el liberalismo ${ }^{170}$.

\section{CONCLUSIONES}

No pretendo resolver aquí la disputada cuestión del origen de las naciones modernas. Si se entiende que el nacionalismo depende de la idea liberal de «soberanía nacional», es obvio que los «serviles» no fueron nacionalistas. Frente al ideal revolucionario que otorgaba a la nación el derecho a constituirse libremente, los «serviles» predicaron un patriotismo retrospectivo basado en la obligada fidelidad a una supuesta tradición religiosa, identitaria y constitucional. Lo cierto es, en cualquier caso, que este patriotismo retrospectivo ha sido una constante entre los reaccionarios españoles, también durante la Restauración y el franquismo.

Varios autores creen que el nacionalismo católico empezó a gestarse en España cuando los conservadores asumieron las ideas románticas. Siguiendo las tesis de Vicente Llorens, Álvarez Junco asume que el romanticismo no llegó a España hasta que, hacia 1833, la élite liberal adoptó ciertas modas culturales extranjeras. Hay, sin embargo, estudiosos que asignan al romanticismo español un origen más temprano, autóctono y conservador ${ }^{171}$. El propio Álvarez Junco encuentra huellas de la «nueva visión romántica» en los escritos de Antonio Capmany durante la Guerra de la Independencia ${ }^{172}$. Lo que no dice es que Capmany fue admirado e imitado por los «serviles» ${ }^{173}$. Tampoco aclara en qué sentido su Centinela contra franceses es más nacionalista o más romántica que otras obras de la misma época tan claramente reaccionarias como el Remedio y preservativo contra el mal francés, de Manuel Freire Castrillón.

Las deudas del conservadurismo romántico español con el pensamiento antiilustrado y reaccionario de la España de finales del xviII y comienzos del

169 Discusión del proyecto (1813): 192; Aldao y Castro (1814): i; Los Guerrilleros por la religión, la patria y el rey, V-3-1813, p. 8.

170 Apéndice al procurador general de la nación y del rey, 19-3-1814, p. 86.

171 Flitter (1992); Silver (1997), y Torrecilla (2016): 68-74 y 268.

172 Álvarez Junco (2001): 136-138 y 148,

173 Centinela contra algunos (1813); El Cristiano Viejo (1813); El Procurador general de la nación y del rey, 8-3-1813, pp. 1301-1305 y 9-3-1814, pp. 512; Alvarado, (1846): 34, y Herrera González (2007): 155-156. 
XIX son, a mi entender, evidentes ${ }^{174}$. Tal vez la recepción del romanticismo europeo transformase esta tradición volviéndola plenamente nacionalista. Pero aún está por explicar en qué consistió esa transformación. No basta con decir que Zorrilla o Fernán Caballero identificaron a España con el catolicismo, porque eso lo habían hecho muchos escritores antes que ellos.

Tampoco resulta convincente la tesis de Manuel Suárez Cortina según la cual el "nacionalcatolicismo» surgió cuando algunos antiliberales, empujados por las circunstancias de la Restauración canovista, transigieron con la modernidad admitiendo el parlamentarismo y cierta tolerancia religiosa ${ }^{175}$. No está claro en qué sentido aceptar a regañadientes una muy limitada tolerancia convierte a alguien en nacionalista. Por lo que respecta al sistema parlamentario — que no es que entusiasmara a los «nacionalcatólicos» de fines del xix-, muchos «serviles» lo acataron más o menos sinceramente e intentaron servirse de él para promover una legislación favorable a su causa.

Sin duda, el patriotismo «servil» estuvo poco organizado y careció de los rituales conmemorativos que proliferaron a finales del siglo xix. Pero algunos «serviles», como el mencionado Freire Castrillón, ya propusieron la creación de fiestas, efemérides, monedas, escudos, premios y hasta de «un cántico y baile nacional» para "memoria y lección perpetua» de los españoles ${ }^{176}$.

Con independencia de dónde se sitúe el origen del nacionalismo reaccionario español, las fuentes evidencian que la propaganda antifrancesa y antiliberal de 1808-1814 exhibió un españolismo que —en su visión de la identidad, la historia y los enemigos de la patria- se asemeja al que luego desarrollaron autores como Balmes o Menéndez Pelayo.

\section{Bibliografía}

Alarcón, M. M. (2012). Las relaciones entre la Corona y la aristocracia durante el reinado de Carlos IV: el caso del XIII duque del Infantado. Pasado y Memoria: Revista de Historia Contemporánea, 11, 165-186. Disponible en: https://doi.org/10.14198/ PASADO2012.11.08.

— (2017). Antiliberales en el escaño durante las Cortes de Cádiz (1810-1813). Hispania, 77 (256), 349-374. Disponible en: https://doi.org/10.3989/hispania.2017.010.

174 Flitter (2006): 60, 74, 95-96, 115-116, 144-145 y 186-193.

175 Suárez Cortina (2010): 275-279.

176 Freire Castrillón (1809): 12, 14-16. 
Aldao y Castro, V. (1814). Fernando VII el más amado. Santiago de Compostela: Juan María de Pazos.

Alonso, G. (2008). «Del altar una barricada, del santuario una fortaleza»: 1808 y la nación católica. En J. Álvarez Barrientos (ed.). La Guerra de la Independencia en la cultura española (75-103). Madrid: Siglo xxi.

Alvarado, F. (1811). Carta crítica de un filósofo rancio que impugna a la española antigua y no a la francesa el discurso del Sr. Diputado Argüelles. Isla de León: Periu.

- (1812a). Segunda carta crítica del Filósofo Rancio. Sevilla: Agustín Muñoz.

- (1812b). Carta décima sexta del Filósofo Rancio. Cádiz: Junta de Provincia.

- (1812c). Carta décima séptima del Filósofo Rancio. Cádiz: Junta de Provincia.

- (1813a). Carta cuarta del Filósofo Rancio. Cádiz: Junta de Provincia.

— (1813b). Carta séptima del Filósofo Rancio. Cádiz: Junta de Provincia.

- (1813c). Carta undécima del Filósofo Rancio. Cádiz: Junta de Provincia.

- (1816). Constitución filosófica que el Filósofo Rancio transformado en Filósofo Liberal escribió antes que las llamadas Cortes Extraordinarias sancionasen su Constitución Politica de la Monarquia Española. Sevilla: Padrino.

(1846). Cartas inéditas. Madrid: José Félix Palacios.

Álvarez Chillida, G. (2002). El antisemitismo en España. Madrid: Marcial Pons.

Álvarez Junco, J. (1994). La invención de la Guerra de la Independencia. Studia Historica-Historia Contemporánea, 12, 75-99.

- (2001). Mater Dolorosa. Madrid: Taurus.

Amado, M. (1831). Dios y España (3 vols.). Madrid: Eusebio Aguado.

Amat, F. (1838). Apéndice a la vida del Illmo. Sr. D. Félix Amat. Madrid: Fuentenebro.

Apología de la Inquisición (1811). Cádiz: Nicolás Gómez de Requena.

Artola, M. (1976). Los origenes de la España Contemporánea (2 vols.). Madrid: Instituto de Estudios Políticos.

Aviso importante y urgente a la nación española (1811). A Coruña: José Voltas.

Barruel, A. (1798). Mémoires pur servir à l'histoire du jacobinisme. Hambourg: P. Fauche.

Borrull, F. J. (1810). Discurso sobre la Constitución que dio al Renio de Valencia su invicto conquistador el Sr. D. Jaime IV. Valencia: Benito Monfort.

Botti, A. (1992). Cielo y dinero: el nacionalcatolicismo en España (1881-1975). Madrid: Alianza.

Calvo Maturana, A. y González Fuertes, M. A. (2008). Monarquía, Nación y Guerra de la Independencia: debe y haber historiográfico en torno a 1808. Cuadernos de Historia Moderna. Anejo, 7, 321-377.

Carnicero, J. C. (1813). Napoleón o el verdadero D. Quijote de la Europa (8 vols.). Madrid: Ibarra.

Caro y Sureda, P (1809). Representación del excmo. señor marqués de la Romana a la Junta Central. Valencia: Benito Monfort.

Cartas de un español residente en París (1788). Madrid: Imprenta Real.

Castro, D. (2011). La nación en las Cortes. Ideas y cuestiones sobre la nación española en el periodo 1808-1814. Cuadernos Dieciochistas, 12, 37-66.

Centinela contra algunos españoles alquilados por Bonaparte para derribar la religión y el trono de España (1813). Manresa: Ignacio Abad. 
Cerezo, L. (1811). El ateísmo bajo el nombre de pacto social propuesto como idea para la Constitución española. Valencia: Francisco Brusola.

Cevallos, F. (1776). La falsa filosofía. Tomo cuarto. Madrid: Antonio Fernández.

- (1813). Observaciones que se han hecho por los años de 1766 sobre la reforma eclesiástica. Santiago: Juan Francisco Montero.

Colón, J. J. (1811). La España vindicada en sus clases y autoridades. Cádiz: Manuel Bosch.

De Jesús, J. M. (1809). ¿¿Debemos esperar o temer? En Demostración de la lealtad española (vol. 4; pp. 3-26). Cádiz: Manuel Jiménez Carreño.

De la Puente, J. (1612). La conveniencia de las dos monarquias católicas. Madrid: Imprenta Real.

De Maistre, J. (1797). Considérations sur la France. Londres.

Decreto definitivo sobre la Inquisición al gusto de los liberales (1813). Cádiz: José María Guerrero.

Demerson, P. (1971). El escrito del Conde de Teba: el Discurso sobre la autoridad de los ricos hombres. Hispania, 117, 137-158.

Diccionario razonado: manual para inteligencia de ciertos escritores que por equivocación han nacido en España (1811). Cádiz: Junta Superior de Gobierno.

Discusión del proyecto de decreto sobre el tribunal de la Inquisición (1813). Cádiz: Imprenta Nacional.

Dorca, F. (1805). Discurso en que se manifiesta que la potestad soberana la reciben los principes inmediatamente de Dios, y no del pueblo. Girona: Vicente Oliva.

Eastman, S. (2005). La que sostiene la Península es guerra nacional: identidades colectivas en Valencia y Andalucía durante la Guerra de la Independencia. Historia y Politica, 14 , 245-272.

- (2012). Preaching Spanish Nationalism across the Hispanic Atlantic, 1759-1823. Baton Rouge: Louisiana State University Press.

Egido, T. (1971). Opinión pública y oposición al poder en la España del siglo XVIII (1713-1759). Valladolid: Universidad de Valladolid.

El Cristiano Viejo (1813). Centinela contra filósofos. Palma: Buenaventura Villalonga.

Elorza, A. (2011). Luz de tinieblas. Nación, independencia y libertad en 1808. Madrid: Centro de Estudios Políticos y Constitucionales.

Espiritu irreligioso de las Reflexiones sociales de D. J. C. A. (1811). Valencia: Yernos de José Esteban.

Esteban de Vega, M. (2005). Castilla y España en la «Historia general» de Modesto Lafuente. En M. Esteban de Vega y A. Morales Moya (coords.). ¿Alma de España?: Castilla en las interpretaciones del pasado español (pp. 87-140). Madrid: Marcial Pons.

F. A. y B. (1813). Prodigiosa vida, admirable doctrina y preciosa muerte de los filósofos liberales de Cádiz. Cádiz: Lema.

Fernández Albaladejo, P. (2007). Materia de España: cultura politica e identidad en la España moderna. Madrid: Marcial Pons.

Fernández Sebastián, J. (1994). España, monarquía y nación. Cuatro concepciones de la comunidad política española entre el Antiguo Régimen y la Revolución liberal. Studia Historica-Historia Contemporánea, 12, 45-74.

Flitter, D. (1992). Spanish Romantic Literary Theory and Criticism. Cambridge: Cambridge University Press. 
(2006). Spanish Romanticism and the Uses of History. London: Legenda.

Forner, J. P. (2010). Discurso sobre el modo de escribir y mejorar la historia de España. Pamplona: Urgoiti.

Freire Castrillón, M. (1809). Remedio y preservativo contra el mal francés. Valencia: Viuda de Martin Peris.

Fuentes, J. F. (2013). Conceptos previos: patria y nación en los orígenes de la España contemporánea. En A. Morales Moya, J. P. Fusi Aizpurúa y A. de Blas Guerrero (dirs.). Historia de la nación y del nacionalismo español (pp. 169-196). Barcelona: Galaxia Gutenberg.

- (2014). España. En J. Fernández Sebastián (dir.). Diccionario político y social del mundo iberoamericano (t. 8, pp. 141-152). Madrid: Centro de Estudios Políticos y Constitucionales.

García Cárcel, R. (2007). El sueño de la nación indomable: los mitos de la Guerra de la Independencia. Madrid: Temas de Hoy.

García de la Huerta, V. (1970). Raquel. Madrid: Castalia.

García Monerris, E. y Escrig Rosa, J. (2016). Apologistas y detractores. El primer discurso antiliberal en la historiografía. En E. García Monerris, I. Frasquet y C. García Monerris (eds.). Cuando todo era posible. Liberalismo y antiliberalismo en España e Hispanoamérica (1780-1842) (pp. 31-72). Madrid: Sílex.

Giralt, V. (1809). Los Macabeos invencibles de la ciudad de Barcelona. Tarragona: Imprenta de la Gaceta.

Gutiérrez y Polop, I. (1809). España regenerada. Valencia: Viuda de Peris.

Hermida, B. R. (1812). Breve noticia de las Cortes, Gobierno, o llámese Constitución del Reino de Navarra. Santiago: Ignacio Aguayo.

Herrera González, J. (2007). ¡Serviles! El grupo reaccionario de las Cortes de Cádiz. Málaga: Fundación Unicaja.

Herrero, J. (1971). Los origenes del pensamiento reaccionario español. Madrid: Editorial Cuadernos para el Diálogo.

Hervás y Panduro L. (1807). Causas de la revolución de Francia. Madrid.

Historia sucinta del liberal Padilla. (1811). Cádiz: Imprenta de Figueroa.

Hocquellet, R. (2008). Resistencia y revolución durante la Guerra de la Independencia. Zaragoza: Prensas Universitarias de Zaragoza.

Junta de Gobierno de Cádiz (1809). Edicto. Cádiz: Nicolás Gómez de Requena.

La lealtad en triunfo (1814). Madrid: Collado.

La Parra, E. (2007). De la disputa cortesana a la crisis de la monarquía. Godoyistas y fernandinos en 1806-1807. Cuadernos de Historia Moderna. Anejos, 6, 255-267.

Lardizábal, M. (1811). Manifiesto que presenta a la nación. Alicante: Nicolás Carratalá Menor y hermanos.

Larrea, F. (1814). Fernando en Zaragoza. Una visión. Cádiz: Niel.

- (2006a). Una aldeana a sus compatricias. En M. Cantos Casenave (ed.). Los episodios de Trafalgar y Cádiz en las plumas de Frasquita Larrea y Fernán Caballero (pp. 73-74). Cádiz: Diputación de Cádiz.

- (2006b). Chiclana. En M. Cantos Casenave (ed.). Los episodios de Trafalgar y Cádiz en las plumas de Frasquita Larrea y Fernán Caballero (pp. 77-78). Cádiz: Diputación de Cádiz. 
- (2006c). Carta al autor del Español. En M. Cantos Casenave (ed.). Los episodios de Trafalgar y Cádiz en las plumas de Frasquita Larrea y Fernán Caballero (pp. 91-93). Cádiz: Diputación de Cádiz.

López, S. (1809). Despertador cristiano-politico. Valencia: Salvador Faulí.

López Alós, J. (2011). Entre el trono y el escaño: el pensamiento reaccionario español frente a la revolución liberal (1808-1823). Madrid: Congreso de los Diputados.

López-Cordón Cortezo, M. V. (2006). De monarquía a nación: la imagen histórica de España en el siglo de la Ilustración. Norba, 19, 151-173.

López de Ulloa, M. M. (1813a). Afectuosos gemidos que los españoles consagran en este día 14 de octubre de 1813. Cádiz: Nicolás Gómez de Requena.

- (1813b). Respuesta de la española autora del papel intitulado Afectuosos gemidos. Cádiz: Nicolás Gómez de Requena.

— (1813c). Fiddelida. Cádiz: Nicolás Gómez de Requena.

Los crimenes constitucionales de Francia (1811). Valencia: Imprenta de Salvador Faulí.

Louzao Villar, J. (2013). Nación y catolicismo en la España contemporánea. Revisitando una interrelación histórica. Ayer, 90, 65-89.

Maravall, J. A. (1967). El sentimiento de nación en el siglo Xviır: la obra de Forner. La Torre, $57,25-56$.

Medina, A. (2009). Espejo de sombras. Sujeto y multitud en la España del siglo XVIII. Madrid: Marcial Pons.

Memorial ajustado hecho de orden del Consejo pleno (1768). Madrid: Joaquín de Ibarra.

Menéndez de Luarca, R. T. (1794). El reino de Dios y su justicia. Santander.

- (1812). Mentidos arbitrios de felicidad. En Viva Jesús. Opúsculos cristiano-patrios. Santiago: Juan Francisco Montero.

Miera Pacheco, J. M. (1809). Discurso pronunciado en la Real Capilla de San Antonio de Aranjuez el día 18 de marzo de 1805. Sevilla: Viuda de Vázquez y Compañía.

Millán, J. (2011). Del poble del regne al poble de la nació. En N. Sauch Cruz (coord.). La guerra del Francès als territoris de parla catalana (pp. 339-341). Catarroja: Afers.

— (2014). La nación desde el antiliberalismo. Patria y monarquía en Lluís M. de Moixó. Alcores, 17, 55-74.

Moliner, A. (2007). A vueltas con la Guerra de la Independencia. Ayer, 66, 253-268.

Mon y Velarde, R., Torres, J. M., Salinas, A. J., Sichar, P., De la Dueńa, F. A., Álvarez de Palma, B. J., Jiménez Sánchez, J. y Arias, V. (1814). Colección de las representaciones y edictos de los obispos refugiados en Mallorca. Valencia: Manuel Muñoz y Compañía.

Moreno Alonso, M. (1989). La generación española de 1808. Madrid: Alianza.

Muñoz Mendoza, J. (2012). La construcción politica de la identidad española: ¿del nacionalcatolicismo al patriotismo democrático? Madrid: Centro de Investigaciones Sociológicas.

Múzquiz y Aldunate, R., Peláez Caunedo, F., Aguiar Caamaño, A., García Benito, J. y Menéndez Luarca, R. (1811). Representación dirigida a las Cortes por el M. R. Arzobispo de Santiago, y RR. Obispos de Lugo, Mondoñedo, Tuy, y Santander. Santiago: Juan Francisco Montero.

Olmeda y León, J. (1771). Elementos del derecho público de la paz, y de la guerra (2 vols.). Madrid: Viuda de Manuel Fernández. 
Ortiz y Sanz, J. F. (1795). Compendio cronológico de la historia de España. Madrid: Imprenta Real.

Ostolaza, B. (1811a). Sermón patriótico-moral. Valencia: Benito Monfort.

- (1811b). Carta sobre el establecimiento del Tribunal de la Inquisición. Cádiz: Manuel Quintana.

Peñalosa y Zuñiga, C. (1793). La Monarquía. Madrid: Viuda de Ibarra.

Pérez de Culla, J. (1811). El editor. En J. F. Masdeu. Discurso sobre las pretensiones de la Francia (pp. 3-8). Valencia: Benito de Monfort.

Pérez Garzón, J. S. (2007). Las Cortes de Cádiz. El nacimiento de la nación liberal (18081814). Madrid: Síntesis.

Pérez Girón, A. (2012). Vicente Terrero, un sanroqueño en las Cortes de Cádiz. San Roque: Ayuntamiento de San Roque.

Pérez y López, A. J. (1785). Principios del orden esencial de la naturaleza. Madrid: Imprenta Real.

Pérez Villaamil, J. (1808). Carta sobre el modo de establecer el consejo de regencia. Madrid: Imprenta de la Hija de Ibarra.

Portillo Valdés, J. M. (2009). Nación-España. En J. Fernández Sebastián (ed.). Diccionario político y social del mundo iberoamericano (vol. 1; pp. 919-928). Madrid: Centro de Estudios Políticos y Constitucionales.

Proclama a los vencedores de los vencedores de Austerlitz y Jena (1808). En Demostración de la lealtad española (vol. 2; pp. 79-80). Cádiz: Manuel Jiménez Carreño.

Puigserver, F. (1815). El teólogo democrático ahogado en las angélicas fuentes. Mallorca: Felipe Guasp.

Quevedo Quintano, P. (1808). Respuesta dada a la Junta de Gobierno.

— (1813). Manifiesto del obispo de Orense a la nación española. La Coruña: Oficina del Exacto Correo.

Representación y manifiesto que algunos diputados a las Cortes ordinarias firmaron (1814). Madrid: Ibarra.

Rina Simón, C. (2015). Los imaginarios franquistas y la religiosidad popular (1936-1949). Badajoz: Diputación de Badajoz.

Rubio Pobes, C. (2014). Patria y nación. En M. Á. Cabrera y J. Pro (coords.). La creación de las culturas políticas modernas: 1808-1833 (pp. 97-126). Madrid: Marcial Pons.

Rújula, P. (2016). El nacimiento de un patriotismo monárquico. En E. García Monerris, I. Frasquet y C. García Monerris (eds.). Cuando todo era posible. Liberalismo y antiliberalismo en España e Hispanoamérica (1780-1842) (pp. 73-95). Madrid: Sílex.

Salazar y Mendoza, P. (1770). Monarquía de España. Tomo I. Madrid: Joaquín Ibarra.

Sánchez-Blanco, F. (2007): La Ilustración goyesca. Madrid: CSIC.

Sanz, T. (1812). La verdad triunfante, o la Sagrada Escritura, la tradición y la historia. Cádiz: Viuda de Comes.

Saz, I. (2012). Visiones de patria entre la dictadura y la democracia. En I. Saz y F. Archilés (eds.). La nación de los españoles (pp. 263-268). Valencia: Universitat de València.

Seoane, M. C. (1968). El primer lenguaje constitucional español. Madrid: Editorial Moneda y Crédito.

Sidro Vilarroig, J. C. (1813). El fraile en las Cortes. Alicante: Manuel Muñoz. 
Silver, P. W. (1997). Ruin and Restitution. Nashville: Vanderbilt University Press.

Solchaga, F. (1809). Carta pastoral y patriótico manifiesto. Sevilla: Imprenta Real.

Suárez Cortina, M. (2008). Catolicismo, identidad nacional y libertad religiosa en la Espańa liberal. En J. Beramendi y M. J. Baz (eds.). Identidades y memoria imaginada (pp. 223-262). Valencia: Universitat de Valencia.

- (2010). El factor religioso y la construcción de la identidad nacional en la España liberal. En M. Suárez Cortina y T. Pérez Vejo (coords.). Los caminos de la ciudadanía (pp. 264-283). Madrid: Biblioteca Nueva.

Terrero, V. (1811): Refutación del periódico La Triple Alianza. Cádiz: Antonio Murguía.

Thiulen, L. I. (1813). Nuevo vocabulario filosófico-democrático. Sevilla: Viuda de Vázquez y Compañía.

Torrecilla, J. (2009a). Guerras literarias del XVIII español: la modernidad como invasión. Salamanca: Universidad de Salamanca.

- (2009b). Spanish Identity: Nation, Myth, and History. Studies in 20th and 21st Century Literature, 33, art. 2.

- (2016). España al revés. Los mitos del pensamiento progresista (1790-1840). Madrid: Marcial Pons.

Torres, J. M., Salinas, A. J., Sichar, P., De la Dueña, F. A., Álvarez de Palma, B. J. y Arias, V. (1813). Instrucción pastoral de los ilustrísimos señores obispos de Lérida, Tortosa, Barcelona, Urgel, Teruel y Pamplona. Mallorca: Brusi.

Traggia, M. (1811). Memoria sobre el derecho de los religiosos al voto en cortes extraordinarias. Valencia: Salvador Faulí.

(1812). El amigo de la verdad. A todo el pueblo español. Mallorca: Brusi.

Vaca de Guzmán, G. J. (1785). Suplemento, o tomo tercero de los viajes de Enrique Wanton al pais de las monas. Madrid: Miguel Escribano.

Varela Suanzes-Carpegna, J. (2007). Política y Constitución en España (1808-1978). Madrid: Centro de Estudios Políticos y Constitucionales.

- (2013). Los dos nacionalismos españoles durante el siglo xIx (a propósito de Mater Dolorosa). En J. Moreno Luzón y F. del Rey Reguillo (coords.). Pueblo y nación: homenaje a José Álvarez Junco (pp. 201-222). Madrid: Taurus.

Vélez, R. (1812). Preservativo contra la irreligión. Cádiz: Junta de Provincia.

Vilallonga, B. (2014). The Theoretical Origins of Catholic Nationalism in Nineteenth-Century Europe. Modern Intellectual History, 11 (2), 307-331.

Vilar, P. (1971). Patrie et nation dans le vocabulaire de la Guerre d'Indépendance espagnole. Annales historiques de la Révolution française, 206, 502-534.

Villanueva, J. L. (1793). Catecismo del Estado según los principios de la religión. Madrid: Imprenta Real. 